\title{
DETECTION OF PHYSIOLOGICAL AND GENOTOXIC DAMAGES REFLECTING TOXICITY IN KALANCHOE CLONES
}

\author{
OZYIGIT I.I. ${ }^{1}$ \\ YILMAZ S. ${ }^{1}$ \\ DOGAN I. ${ }^{2,3}$ \\ SAKCALI M.S. ${ }^{4}$ \\ TOMBULOGLU G. ${ }^{5}$ \\ GOKSEL DEMIR G. ${ }^{6}$
}

\author{
${ }^{1}$ Marmara University, Faculty of Sciences \& Arts \\ Department of Biology, 34722, Goztepe/Istanbul-Turkey \\ ${ }^{2}$ Izmir Institute of Technology, Faculty of Science \\ Department of Molecular Biology \& Genetics, 35430, Urla/Izmir-Turkey \\ ${ }^{3}$ Kyrgyz-Turkish Manas University, Faculty of Science \\ Department of Biology, 72001, Bishkek-Kyrgyzstan \\ ${ }^{4}$ Suleyman Demirel University, Faculty of Arts \& Sciences \\ Department of Biology, 32260 Isparta/Turkey \\ ${ }^{5}$ Fatih University, Vocational School of Medical Sciences \\ Program of Pathology Laboratory Techniques, 34844, Maltepe/Istanbul, Turkey \\ ${ }^{6}$ Kirklareli University, Faculty of Architecture \\ Department of Urban \& Regional Planning, 39020, Kayali/Kirklareli-Turkey
}

Received: $27 / 01 / 2014$

Accepted: 24/02/2016

Available online: $13 / 04 / 2016$

*to whom all correspondence should be addressed: e-mail: ilhandogan@iyte.edu.tr

\section{ABSTRACT}

In order to make assessments in understanding of physiological and genotoxic effects of imposing cadmium ( $\mathrm{Cd}$ ) on photosynthetic pigment contents along with the changes occurring in genetic material of Kalanchoe plants were used in relation to various $\mathrm{Cd}$-treatments. Young plantlets were originated from a single host plant as clones, and developed in vitro. Developed clones were grown in standard pots with daily watering of Hoagland solution $(20 \mathrm{ml})$ containing different concentrations of cadmium chloride for two months. Cd concentrations of the collected samples were measured by employing ICP-OES and RAPDPCR technique was applied for detecting the genotoxic effects of $\mathrm{Cd}$. After two month of experimental period, the comparisons between unexposed and exposed Kalanchoe clone groups revealed reductions in photosynthetic pigment contents, especially at the highest level of $\mathrm{Cd}$ exposure and a genomic instability when application of $\mathrm{Cd}$ concentration increases. RAPD-PCR analyses demonstrated the distinguishable banding pattern in number and band intensities between Cd-treated and control groups. In addition, progressive $\mathrm{Cd}$ accumulations in leaves, stems and roots of plant samples were observed when the application of exposure level increased.

Keywords: RAPD-PCR, heavy metal pollution, photosynthetic pigments, genotoxicity

\section{Introduction}

Heavy metal pollution is one of the most serious problems in human history and it has gained more impetus in recent decades due to the heavy reliance of heavy metal utilizations in industries. Heavy metals accumulated in soil, water and air could persist for many years and therefore they create potential risks for ecosystems (Duruibe et al., 2007; Lone et al., 2008; Wang et al., 2012).

Recently, Cd utilization in much of the modern world has been progressively increased. Consequently, Cdrelated toxicity has become a serious problem for the environment. $\mathrm{Cd}$ could be taken up by plants

Ozyigit I.I., Yilmaz S., Dogan I.,_Sakcali M.S., Tombuloglu G. and Demir G. (2016), Detection of physiological and genotoxic damages reflecting toxicity in Kalanchoe clones, Global NEST Journal, 18(1), 223-232. 
although it is not an essential for plant life (Xu et al., 2012; Zhao et al., 2014). Prolonged exposure or accumulation of $\mathrm{Cd}$ by plants could cause the various toxicity-related consequences such as reduced photosynthesis (Mobin and Khan, 2007), generation of reactive oxygen species (ROS) (Schutzendubel et al., 2001), inhibited respiration (Seregin and Ivanov, 2001) and cell proliferation (Liu et al., 2003; Deckert, 2005), diminished water balance (Sandalio et al., 2001; Garinova et al., 2007; Wan et al., 2011), and disturbed carbohydrate (Lorenc-Plucinska and Stobrawa, 2005) and nutrient uptake metabolisms (Wu and Zhang, 2002; Zhang et al., 2002) resulting in visible symptoms such as chlorosis, necrosis, root blackening, stunting and general reductions in biomass production (Sandalio et al., 2001). Although plants have elaborative mechanisms to eliminate or alleviate the environmental stress factors to some point, excessive levels of heavy metals could cause the substantial cellular stress subsequently giving damages to the various cellular components such as DNA, proteins and membranes (Zhang et al., 2005; Bertin and Averbeck, 2006; Liu et al., 2009). For example, Cd could induce the generation of ROS, whose subsequent accumulation leads the oxidative stress finally causing to enzyme inhibition, lipid peroxidation, DNA/RNA damage and/or protein oxidation (Mittler, 2002).

Kalanchoe daigremontiana is a succulent CAM plant but is not a halophyte one (Bartha and Fodorpataki 2007). Although it is native to Madagascar, it is distributed in many parts of tropical and subtropical Africa, Asia, North America and South Africa as well as found in Bangladesh (Nahar et al., 2008).

In this research, possible physiological and genotoxic effects of $\mathrm{Cd}$ were investigated in Kalanchoe plants grown under different levels of $\mathrm{Cd}$ exposures. For detecting genotoxicity, the RAPD-PCR (Randomly Amplified Polymorphic DNA) technique was employed and photosynthetic pigment contents were evaluated in order to make assessments for the effects of Cd toxicity. Using RAPD-PCR in assessing of genotoxic effects of heavy metals is commonly used technique, which enables to detect the DNA band features such as band intensity and gain or loss in relation to toxicant exposures (Atienzar \& Jha, 2006; Swaileh et al., 2008; Kekec et al., 2010). Therefore, this study results will pave the way for understanding of alterations in genetic material in relation to heavy metal exposure such as $\mathrm{Cd}$ as well as in changes of metabolic processes relatedly.

\section{Materials and methods}

\subsection{In vitro development of Kalanchoe plantlets}

Kalanchoe plantlets (clones) were obtained from the leaves of a single host plant and grown on wet filter papers in glass dishes in growth chamber under 4000-4200 lux of irradiance with day (14)/night (10) regimens, respectively, $23 \pm 2^{\circ} \mathrm{C}$ temperature and $50-55 \%$ relative humidity. Plantlets were daily watered with $20 \mathrm{ml}$ of full strength Hoagland solution for 14 days (Hoagland and Arnon, 1950). Following in vitro development, 90 young plantlets were transferred into standard plastic pots (Gardol ${ }^{\circledR}$ ) containing sterilized compost (161.5 g). Appearing the second mature leaves, each experimental group (5 plantlets) was daily watered with $20 \mathrm{ml}$ of Hoagland solution containing $0,50,100,200$ and $400 \mu \mathrm{M}$ of $\mathrm{Cd}$ (in $\mathrm{CdCl}_{2}$ form) for 60 days. For control and experimental groups, $\mathrm{pH}$ value was kept as 5.6. At the end of 60 -days experimental period, plantlets were harvested for RAPD and the content of photosynthetic pigment analyzes.

\subsection{Determination of the contents of photosynthetic pigments}

Photosynthetic pigments were extracted in $15 \mathrm{ml}$ of $80 \%$ acetone $(\mathrm{v} / \mathrm{v})$ using $0.5 \mathrm{~g}$ of leaf materials from each sample and then extraction was centrifuged at $3000 \mathrm{~g}$ and $+4{ }^{\circ} \mathrm{C}$ for $10 \mathrm{~min}$. Wavelengths used in chlorophyll $a$ and $b$, and carotenoid measurements include 645, 663 and $470 \mathrm{~nm}$, respectively. Chlorophyll $a$ and $b$, and carotenoids concentrations were calculated according to relevant literature (Arnon, 1949) as followed below;

$$
\begin{aligned}
& C_{a}=\left[12.7 \times D_{663}-2.69 \times D_{645}\right] \times V / 1000 \\
& C_{b}=\left[22.9 \times D_{645}-4.68 \times D_{663}\right] \times V / 1000
\end{aligned}
$$




$$
\begin{gathered}
C_{\text {Total }}=\left[20.2 \times D_{645}+8.02 \times D_{663}\right] \times V / 1000 \\
C_{x+c}=1000 D_{470}-1.90 C_{a}-63.14 C_{b} / 214 \times V / 1000
\end{gathered}
$$

Where $C_{a}$ is the chlorophyll $a$ concentration $\left(\mathrm{mg} \mathrm{ml}^{-1}\right), C_{b}$ is the chlorophyll $b$ concentration $\left(\mathrm{mg} \mathrm{ml}^{-1}\right), C_{\text {Total }}$ is the total chlorophyll concentration $\left(\mathrm{mg} \mathrm{ml}^{-1}\right), C_{x+c}$ is the carotenoids concentration $\left(\mathrm{mg} \mathrm{ml}^{-1}\right), D_{663}, D_{645}$ and $D_{470}$ are the optical density at 663,645 and $470 \mathrm{~nm}$, respectively, and $V$ is the volume of the supernatant obtained after the centrifugation $(\mathrm{ml})$.

\subsection{Analysis of $\mathrm{Cd}$ accumulation in plant samples}

Root, stem and leaf samples taken from the plants were oven-dried at $80^{\circ} \mathrm{C}$ for $24 \mathrm{~h}$. Then, the samples were milled in a micro-hammer cutter and fed through a $1.5-\mathrm{mm}$ sieve. Later, samples were weighed as $0.5 \mathrm{~g}$ and transferred into Teflon vessels. Following the addition of $8 \mathrm{ml} 65 \% \mathrm{HNO}_{3}$, the samples were mineralized in microwave oven (Berghof - MWS2) at $145^{\circ} \mathrm{C}$ for $5 \mathrm{~min}, 165^{\circ} \mathrm{C}$ for $5 \mathrm{~min}$ and $175^{\circ} \mathrm{C}$ for 20 min. After cooling of the samples, they were filtered by Whattman papers and made up to $50 \mathrm{ml}$ with ultra-pure water and stored in falcon tubes. Then, standard solution was prepared and $\mathrm{Cd}$ concentrations were measured using Inductively Coupled Plasma Optical Emission Spectroscopy (PerkinElmer-Optima 7000 DV).

\subsection{Analysis of genotoxic effects}

RAPD analysis was performed to analyze the genotoxic effects of $\mathrm{Cd}$ in plant samples. DNA isolation was carried out using DNeasy Plant DNA Extraction Mini Kit (Qiagen) according to supplier's instructions. PCR mix was prepared for $25 \mu \mathrm{l}$, containing $1 \times$ PCR buffer $\left(\mathrm{NH}_{4}\right)_{2} \mathrm{SO}_{4}, 0.2 \mathrm{mM}$ from each dNTP (2 mM dNTP mix), 25 picomoles of primer OPA08 5' CCACAGCAGT 3' (QIAGEN Operon RAPD ${ }^{\circledR} 10$ mer Kits), 20-200 ng of genomic DNA, and 0.5 units of Taq DNA polymerase, and filled up with sterile de-ionized water to final volume. Tubes containing all reaction components, except template DNA, were included as controls for each reaction. Amplication was performed using Techne Endurance TC-512 Gradient Thermal Cycler at $95{ }^{\circ} \mathrm{C}$ for $3 \mathrm{~min}$. followed by $45 \mathrm{cycles}$ of $1 \mathrm{~min}$. at $94{ }^{\circ} \mathrm{C}, 1 \mathrm{~min}$. at $37{ }^{\circ} \mathrm{C}, 2 \mathrm{~min}$. at $72{ }^{\circ} \mathrm{C}$, and $5 \mathrm{~min}$. at $72{ }^{\circ} \mathrm{C}$. Amplification products were analyzed and estimated using 100bp DNA ladder/marker (Gene Ruler ${ }^{\mathrm{TM}} 100$ bp DNA Ladder, ready-to-use, MBI Fermentas) in 2\% agarose gel, stained with ethidium bromide. Results were documented using GelDoc 2000 (BioRAD) gel documentation system. Clearly observed bands were scored to create the genetic profiles of plant samples. Based on the band intensity, and loss or gains, genomic instability and DNA variations were estimated.

\section{Results}

\subsection{Photosynthetic pigments in Kalanchoe plantlets exposed to $\mathrm{Cd}$ at different levels}

Considerable reductions were observed on photosynthetic pigment contents of Kalanchoe plants after 60 days of $C d$ exposure at different levels in comparison with control group $(0,50,100,200$ and $400 \mu \mathrm{M})$ (Fig. 1). The reduction rates were $\sim 40.57 \%$ for chlorophyll $a$ (from $0.212 \mathrm{mg} \mathrm{ml}^{-1}$ to $0.126 \mathrm{mg} \mathrm{ml}^{-1}$ ) (Fig. 1A), $37.63 \%$ for chlorophyll $b$ (from $0.093 \mathrm{mg} \mathrm{ml}^{-1}$ to $0.058 \mathrm{mg} \mathrm{ml}^{-1}$ ) (Fig. 1B), $20.58 \%$ for chlorophyll $a / b$ (from $2.293 \mathrm{mg} \mathrm{ml}^{-1}$ to $1.821 \mathrm{mg} \mathrm{ml}^{-1}$ ) (Fig. 1D), $36.27 \%$ for total chlorophyll (from $0.284 \mathrm{mg} \mathrm{ml}^{-1}$ to 0.181 $\mathrm{mg} \mathrm{ml}^{-1}$ ) (Fig. 1C)and $~ 37.66 \%$ for carotenoids (from $0.077 \mathrm{mg} \mathrm{ml}^{-1}$ to $0.048 \mathrm{mg} \mathrm{ml}^{-1}$ ) (Fig. 1E) under severe Cd stress $(400 \mu \mathrm{M} \mathrm{Cd})$. Slight increases in the contents of chlorophyll $a$, chlorophyll $b$, chlorophyll $a / b$, total chlorophyll and carotenoids were noticed at the level of $100 \mu \mathrm{M} C d$ treatment in comparisons with the levels of 50, 200 and $400 \mu \mathrm{M}$ Cd treatments. Overall, it was revealed that the chlorophyll $a, b, a / b$, total chlorophyll and carotenoid contents of Kalanchoe plants were substantially decreased when different levels of $\mathrm{Cd}$ were applied.

\subsection{Accumulation of $\mathrm{Cd}$ in different parts of the plant grown in different levels of $\mathrm{Cd}$ exposure}

Dramatic increases in $\mathrm{Cd}$ concentrations were detected in the leaves (from $0.629 \mathrm{mg} \mathrm{ml}^{-1}$ to 3.164 $\mathrm{mg} \mathrm{ml}^{-1}$ ) (Fig. 2A), stems (from $0.460 \mathrm{mg} \mathrm{ml}^{-1}$ to $2.890 \mathrm{mg} \mathrm{ml}^{-1}$ ) (Fig. 2B) and roots (from $1.327 \mathrm{mg} \mathrm{ml}^{-1}$ to 
$5.178 \mathrm{mg} \mathrm{ml}^{-1}$ ) (Fig. 2C) of Kalanchoe plants when increasing levels of $\mathrm{Cd}$ were applied (Fig. 2). The rates of increases at the level of $400 \mu \mathrm{M}$ treatments were found to be $\sim 5.03$ fold in leaves, $\sim 6.28$ fold in stems and $\sim 3.90$ fold in roots of Kalanchoe plants. The data reveals that the accumulation of $\mathrm{Cd}$ was mainly seen in all parts of the plant and was progressive when increasing amount of exogenous $\mathrm{Cd}$ was applied.

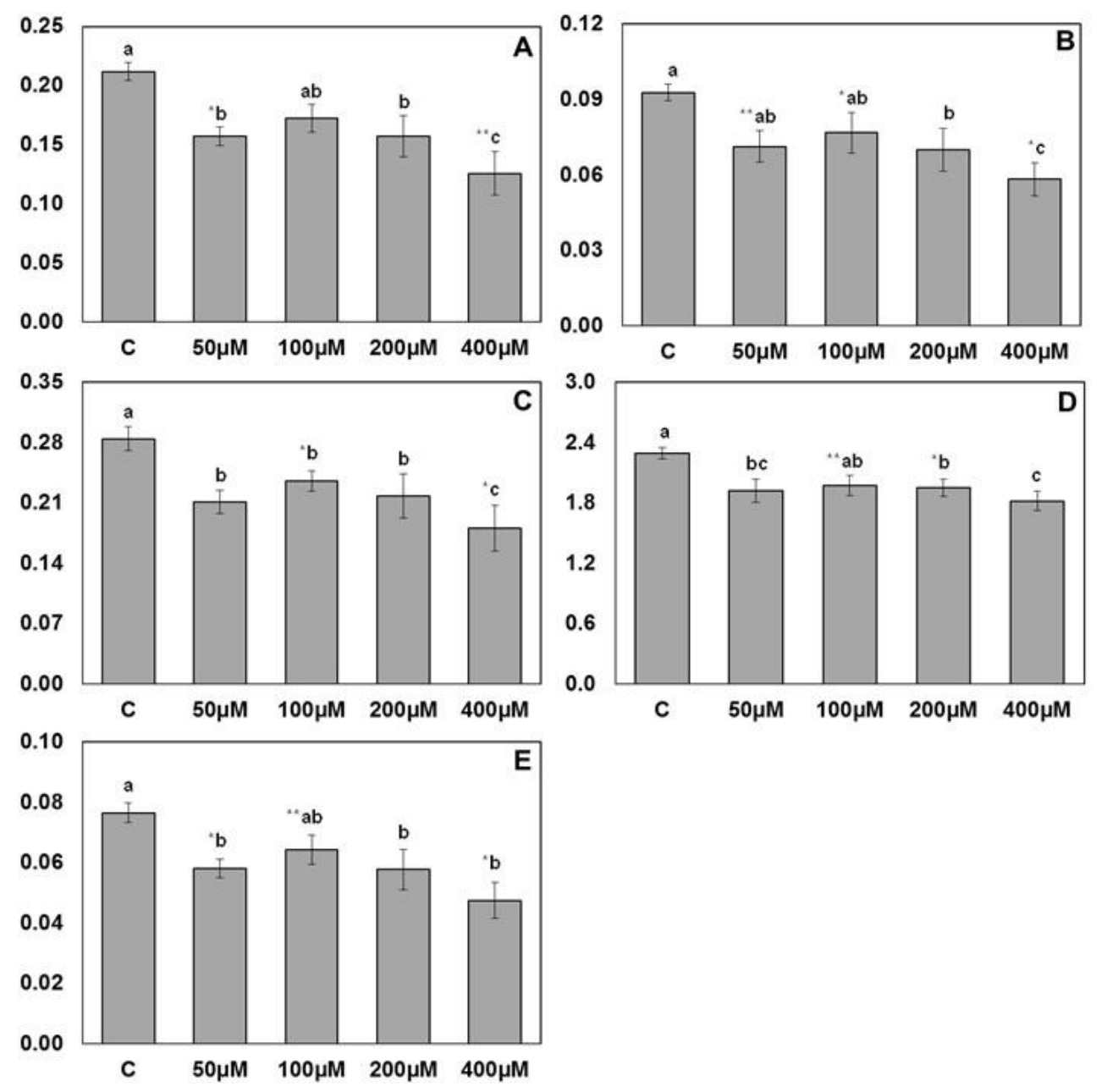

Figure 1. Pigment concentrations ( $\mathrm{mg} \mathrm{ml}^{-1}$ ) of controls (C) and Cd-treated (50, 100, 200 and $\left.400 \mu \mathrm{M}\right)$ Kalanchoe leaves. A) Chlorophyll $a$, B) Chlorophyll $b$, C) Total Chlorophyll, D) Chloropyll $a / b$, e) Carotenoids. The mean difference is significant at $0.01\left(^{* *}\right)$ and $0.05(*)$ levels by the Tukey HSD and multivariate analysis of variance (MANOVA)

Different application levels of $\mathrm{Cd}$ (up to $800 \mu \mathrm{M}$ ) were used in researches related with Cd toxicity (Yang et al., 2004; Nedjimi and Daoud, 2009; Goncalves et al., 2009; Meng et al., 2009). By previous studies performed by Wagner (1993), and Sanita di Toppi and Gabrielli (1999), Cd concentrations (in mM) were found to be between 0.04-0.32 in unpolluted and 0.32-1 in moderate level of polluted soils, respectively. Between 0.2-0.8 mg kg-1 DW of $\mathrm{Cd}$ was reported as normal ranges whereas between/over 5-30 mg kg-1 DW of Cd was accepted as toxic levels for plants (Ross 1994; Kabata-Pendias and Pendias, 2001). When taken into consideration of above-mentioned literatures, $\mathrm{Cd}$ concentrations used in this study were chosen in 0-400 $\mu \mathrm{M}$ range.

\subsection{Detection of genotoxicity in leaf tips of Kalanchoe plantlets exposed to Cd at different levels}

Genotoxic effect of different $\mathrm{Cd}$ concentrations on Kalanchoe genome were evaluated by comparing RAPD-PCR band profiles. RAPD-PCR analysis was carried out using DNA taken from leaves of Kalanchoe plants exposed to $C d$ at different levels $(0,50,100,200$ and $400 \mu \mathrm{M})$ for 60-day experimental period. 
Distinguishable banding patterns in number and band intensities including increase or decrease in band intensities and loss or gain of bands were produced using primer designated as OPA08 (CCACAGCAGT, QIAGEN Operon RAPD ${ }^{\circledR} 10$ mer Kits) between exposed and unexposed (control) groups (Table 1). The representative RAPD-PCR band profiles are shown in Fig. 3 as well as Table 2. Distinctive RAPD-PCR band patterns due to alterations (i.e. increase or decrease in band intensities and the loss or the gain of bands) were obtained based on comparisons performed between DNAs of $\mathrm{Cd}$-exposed and unexposed plantlets.

Table 1. Number and intensity changes of RAPD-PCR profiles (a, b, c, and d) detected with primer OPA-08 in Cd-exposed Kalanchoe plantlets in comparison to the unexposed Kalanchoe plantlets.

\begin{tabular}{|c|c|c|c|c|c|}
\hline Cd concentrations $(\mu \mathrm{M})$ & Total band numbers & a & b & c & d \\
\hline Control & 3 & - & - & - & - \\
\hline $50 \mu \mathrm{M}$ & 5 & 2 & - & - & 2 \\
\hline $100 \mu \mathrm{M}$ & 3 & - & - & 1 & - \\
\hline $200 \mu \mathrm{M}$ & 6 & 3 & - & - & 2 \\
\hline $400 \mu \mathrm{M}$ & 4 & 1 & - & - & 1 \\
\hline
\end{tabular}

a: indicates the number of new bands, $\mathbf{b}$ : indicates the number of disappearing normal bands, $\mathbf{c}$ : indicates the number of normal bands having a decrease in band intensity and $\mathbf{d}$ : indicates the number of normal bands having an increase in band intensity. -: indicates none detected bands.
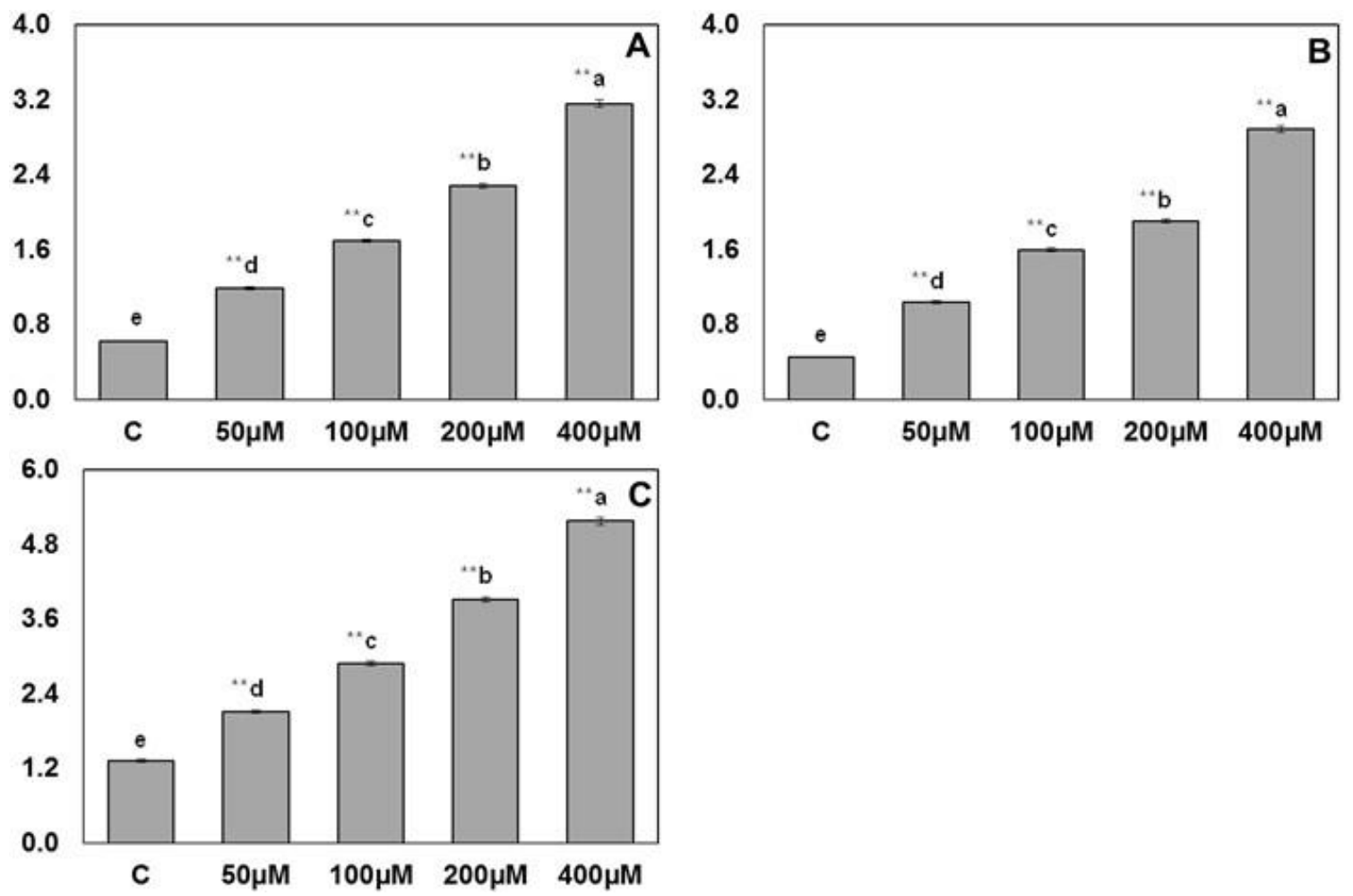

Figure 2. Concentrations of $\mathrm{Cd}\left(\mathrm{mg} \mathrm{kg}^{-1} \mathrm{DW}\right)$ in controls $(\mathrm{C})$ and leaf, stem and root samples of Kalanchoe plants grown in different levels of $\mathrm{Cd}(0,50,100,200$ and $400 \mu \mathrm{M})$ for two months.

A) Leaf, B) Stem and C) Root. The mean difference is significant at $0.01\left({ }^{* *}\right)$ level by the Tukey HSD and multivariate analysis of variance (MANOVA)

The molecular sizes of obtained bands using OPA08 demonstrated a range of 123-822 bp. Decreases and increases in band intensities were found to be existed at all level of $\mathrm{Cd}$ treatments. Decrease in band intensity was indicated at the level of $100 \mu \mathrm{M}$ of Cd-treatment whereas increases were found at the levels of 50, 200 and $400 \mu \mathrm{M}$ Cd-treatments with the molecular sizes of 402 and 648 bp (Table 2 and Fig. 3). Extra bands appeared at the levels of 50,200 and $400 \mu \mathrm{M}$ of $\mathrm{Cd}$ treatments with molecular sizes of 286 , 312, 348, 712 and 822 bp whereas there was no normal band disappearance (Table 2 and Fig. 3). 
Table 2. Molecular sizes (bp) of appearing and disappearing bands, and changes in band intensities

\begin{tabular}{|c|c|c|c|c|}
\hline \multirow{2}{*}{ Cd concentrations ( $\mu \mathrm{M})$} & \multicolumn{4}{|c|}{ RAPD bands } \\
\hline & a & b & C & d \\
\hline $50 \mu \mathrm{M}$ & 312,286 & - & - & 648,402 \\
\hline $100 \mu \mathrm{M}$ & - & - & 123 & - \\
\hline $200 \mu \mathrm{M}$ & $822,712,286$ & - & - & 648,402 \\
\hline $400 \mu \mathrm{M}$ & 348 & - & - & 402 \\
\hline
\end{tabular}

a: indicates appearance of new bands, b: indicates disappearance of normal bands, $\mathbf{c}$ : indicates decrease in band intensities and $\mathbf{d}$ : indicates increase in band intensities. -: indicates none detected bands.

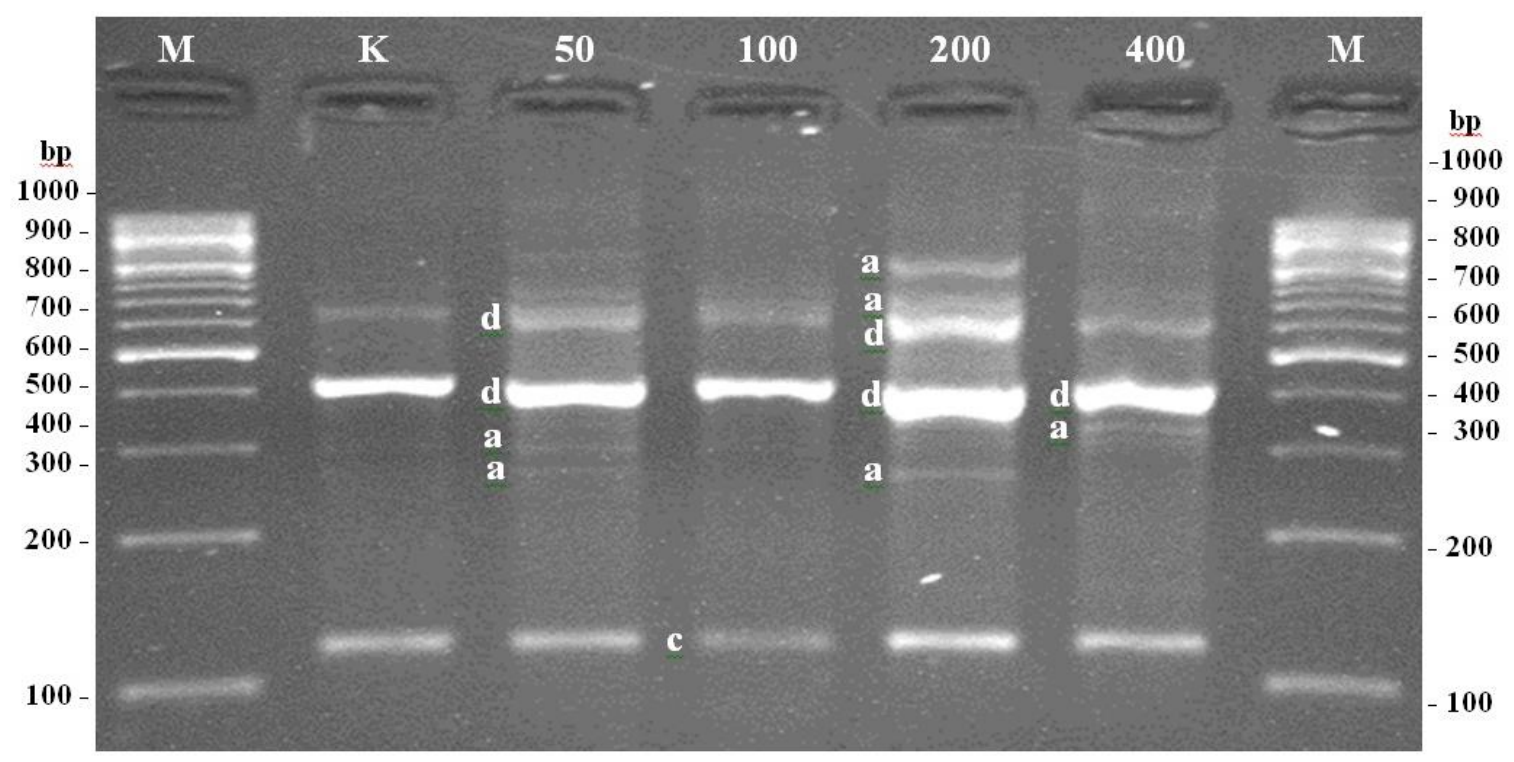

Figure 3. RAPD-PCR band profiles of Kalanchoe plantlets exposed to different Cd concentrations at the levels of 50, 100, 200 and $400 \mu \mathrm{M}$. a: appearance of new bands, b: disappearance of normal bands, c: decrease in band intensities, $\mathbf{d}$ : increase in band intensities. M: 100 bp DNA Ladder, K: Control

\section{Discussion}

In this work, Cd was found to have suppressive effects on photosynthetic pigment concentrations in Kalanchoe plantlets. Cd over normal limits could produce cellular responses other than regular and prolonged exposure of $\mathrm{Cd}$ appears to be having negative effects on different cellular structures (Bertin and Averbeck, 2006; Liu et al., 2009). Cd-related oxidative stress in cells induces occurrences of ROS, which consequently leads to the enzyme inactivation, DNA damage and lipid peroxidation (Sandalio et al., 2001; Mittler, 2002; Gichner, 2003; Sun et al., 2007). In our study, reductions were observed in the pigment concentrations of Cd-exposed Kalanchoe leaves at the levels of 50,100, 200 and $400 \mu \mathrm{M}$; however, a slight deviation was noticed at the level of $100 \mu \mathrm{M}$ in comparisons with the levels of 50 and $200 \mu \mathrm{M}$. Taking into account the physiological parameters, it could be said that the plant tries to take necessary adjustments to compensate negative effects of $\mathrm{Cd}$ in some degree by carrying out some modifications but after a certain point, $\mathrm{Cd}$ toxicity becomes inevitable for the plant.

The results from RAPD-PCR profile analysis showed that the appearance of extra bands and increases in band intensities at the levels of 50, 200 and $400 \mu \mathrm{M} \mathrm{Cd}$. A decrease in band intensity was also observed at the level of $100 \mu \mathrm{M} \mathrm{Cd}$. The reasons could be related with Cd-derived DNA damage(s) causing the genomic instabilities. Overall changes at genomic DNA level in relation to Cd-exposure indicate that abiotic environmental factors, including heavy metals could have influential effects on appearance of new individual characteristics in plants. By previous researches it was demonstrated that $\mathrm{Cd}$ toxicity could 
cause various damages at DNA level, including base modifications and oxidations, single and double strand breaks, DNA-protein cross links, abasic sites, bulky adducts and DNA lesions such as 8-hydroxyguanine in organisms (Bisova et al., 1993; Hsiao and Stapleton, 2004). The occurrence of these various DNA mutations and lesions could also generate the substantial structural changes in genetic material thereby affecting the PCR kinetics (Bowditch et al., 1993). Thus, appearances and disappearances in RAPD band profiles could have been arisen from the availability or absence of priming site/s in relation to these structural modifications in DNA sequences (Atienzar et al., 1999).

DNA fingerprinting was reported to be an important bio-indicator used in evaluation of toxicants' effects (Atienzar et al., 1999; Becerril et al., 1999; Grayson et al., 1999). The pollutant-induced changes in RAPD profiles were used to comparatively analyze the alterations in genomic DNA stability and genotoxic effects with other parameters (Atienzar et al., 2000; Liu et al., 2005). In this work, the levels of photosynthetic pigments, including chlorophyll $a, b, a / b$, total chlorophyll and carotenoids in leaf tips of Kalanchoe were demonstrated to be used as a biomarker in detection of Cd effects. Similar studies were also performed by others (Hou et al., 2007; Maurya et al., 2008; Mishra et al., 2008). Also, it was revealed that Cd was progressively accumulated in all parts of Kalanchoe plants when increasing amount of exogenous Cd was applied. Similar results from previous studies were also reported (Salt et al., 1995; Hart et al., 1998; Uraguchi et al., 2009; Prasad et al., 2001). The reductions in photosynthetic pigment contents in Kalanchoe plants exhibited an inverse relationship with the level of $\mathrm{Cd}$ applied (except the level of 100 $\mu \mathrm{M}$ ) and our findings were in agreement with previous the studies (Hou et al., 2007; Maurya et al., 2008; Mishra et al., 2008). Alterations in both photosynthetic pigment levels and RAPD-PCR profiles of Kalanchoe plants were well correlated. It seemed that extent of DNA damage could be serious in majority of leaf tip cells in Kalanchoe plants. Recently, similar observations were shown by similar investigations. For example, the reduced photosynthetic pigment concentrations and RAPD profile changes in Brassica rapa and watercress (Nasturtium officinale) plants were reported in response to lead $(\mathrm{Pb})$ and arsenic (As) treatments, respectively (Cenkci et al., 2010; Ozturk et al., 2010). Aly (2012) reported the significant decreases in photosynthetic pigment contents and genetic alterations in Egyptian clover and Sudan grass in relation to $\mathrm{Cd}$-exposure. In another study, accumulation of heavy metals, including $\mathrm{Cd}, \mathrm{Pb}$ and $\mathrm{Zn}$ in Hibiscus rosa-sinensis were found to influence the photosynthetic pigment contents as well as to induce the DNA changes (Bhaduri and Fulekar, 2014). All these studies indicate that there could be a positive correlation between genomic template stability and photosynthetic pigment content parameters in relation to heavy metal treatments.

\section{Conclusions}

In the present research, induced genomic alterations and changes in some physiological parameters were detected in Kalanchoe plants grown in the presence of $\mathrm{Cd}$. Reductions in photosynthetic pigments, and genomic instabilities were detected after applications of $50 \mu \mathrm{M}, 100 \mu \mathrm{M}, 200 \mu \mathrm{M}$ and $400 \mu \mathrm{M} \mathrm{Cd}$ concentrations by the comparisons done between unexposed and exposed Kalanchoe clone groups. The obtained results suggest that the data from RAPD-PCR analysis along with the data from and physiological parameters can be used together for estimation of $\mathrm{Cd}$ pollution.

\section{Acknowledgement}

This study was funded by Marmara University, Commission of Scientific Research Project under grant FEN-C-YLP040712-0283.

\section{References}

Aly A.A. (2012), Application of DNA (RAPD) and ultrastructure to detect the effect of cadmium stress in Egyptian clover and Sudan grass plantlets, Journal of Stress Physiology \& Biochemistry, 8(1), 241-257. 
Arnon D.I. (1949), Copper enzymes in isolated chloroplasts, polyphenoxidase in Beta vulgaris, Plant Physiology, 24, 1-15.

Atienzar F.A., Cordi B. and Evenden A.J., (1999), Qualitative Assessment of Genotoxicity Using Random Amplified Polymorphic DNA: Comparison of Genomic Template Stability with Yey Fitness Parameters in Daphnia magna Exposed to Benzo[a]pyrene, Environmental Toxicology and Chemistry, 18, 2275-2282.

Atienzar F.A., Cordi B. and Donkin M.E. (2000), Comparison of 442 Ultraviolet-Induced Genotoxicity Detected by Random Amplified Polymorphic DNA with Chlorophyll Fluorescence and Growth in A Marine Macroalgae, Aquatic Toxicology, 50, 1-12.

Atienzar F.A. and Jha N.A. (2006), The random amplified polymorphic DNA (RAPD) assay and related techniques applied to genotoxicity and carcinogenesis studies: A critical review, Mutation Research, 613, 76-102.

Bartha L. and Fodorpataki L. (2007), Physiological reactions of the succulent CAM plant Bryophyllum daigremontianum to increased salinity, Contributions Botany, 42, 47-56.

Becerril C., Ferrero M., Sanz F. and Castano A. (1999), Detection of mitomycin C-induced genetic damage in fish cells by use of RAPD, Mutagenesis, 14, 449-456.

Bertin G. and Averbeck D. (2006), Cadmium: Cellular Effects, Modifications of Biomolecules, Modulation of DNA Repair and Genotoxic Consequences, Biochimie, 88, 1549-1559.

Bhaduri A.M. and Fulekar M.H. (2014). Biochemical and RAPD analysis of Hibiscus rosa sinensis to assess the effects induced by heavy metals, Soil and Sediment Contamination, (accepted manuscript) DOI:10.1080/15320383.2015.970683.

Bisova K., Hendrychova J., Cepak V. and Zachleder V. (1993), Cell Growth and Division Processes Are Differentially Sensitive to Cadmium in Scenedesmus quadricauda, Folia Microbiologica (Praha), 48, 805-816.

Bowditch B.M., Albright D.G. and Williams J.G.K. (1993), Use of Randomly Amplified Polymorphic DNA Markers in Comparative Genomic Studies, Methods Enzymology, 224, 294-309.

Cenkci S., Cigerci I.H., Yildiz M., Ozay C., Bozdag A. and Terzi H. (2010), Lead contamination reduces chlorophyll biosynthesis and genomic template stability in Brassica rapa L., Environmental and Experimental Botany, 67, 467-473.

Deckert J. (2005), Cadmium toxicity in plants: Is there any analogy to its carcinogenic effect in mammalian cells? BioMetals, 18, 475-481.

Duruibe J.O., Ogwuegbu M.O.C. and Egwurugwu J.N. (2007), Heavy metal pollution and human biotoxic effects, International Journal of Physical Sciences, 2(5), 112-118.

Garinova N., Nedkovska M., Todorovska E., Simova-Stoilova L., Stoyanova Z., Georgieva K., Demirevska-Kepova K., Atanassov A. and Herzig R. (2007), Improved phytoaccumulation of cadmium by genetically modified tobacco plants (Nicotiana tabacum L.), Physiological and biochemical response of the transformants to cadmium toxicity, Environmental Pollution, 145(1), 161-170.

Gichner T. (2003), DNA Damage Induced by Indirect and Direct Acting Mutagens in Catalase-Deficient Transgenic Tobacco: Cellular and Acellular Comet Assays, Mutation Researc, 535, 187-193.

Goncalves J.F., Antes F.G., Maldaner J., Pereira L.B., Tabaldi L.A., Rauber R., Rossato L.V., Bisognin D.A and Dressler V.L. (2009), Cadmium and mineral nutrient accumulation in potato plantlets grown under cadmium stress in two different experimental culture conditions, Plant Physiology and Biochemistry, 47(9), 814-821.

Grayson T.H., Cooper L.F., Atienzar F.A., Knowles M.R. and Gilpin M. (1999), Molecular differentiation of Renibacterium salmoninarum isolates from world-wide locations, Applied and Environmental Microbiology, 65, 961-968.

Hart J.J., Welch R.M., Norvell W.A., Sullivan L.A. and Kochian L.V. (1998), Characterization of Cadmium Binding, Uptake, and Translocation in Intact Seedlings of Bread and Durum Wheat Cultivars, Plant Physiology, 116, 1413-1420.

Hou W., Chen X., Song G., Wang Q. and Chang C.C. (2007), Effects of copper and cadmium on heavy metal polluted waterbody restoration by duckweed (Lemna minor), Plant Physiology and Biochemistry, 45(1), 62-69.

Hoagland D.R. and Arnon D.I. (1950), The water-culture method for growing plants without soil. Berkeley, Calif.: University of California, College of Agriculture, Agricultural Experiment Station. 
Hsiao C.J. and Stapleton S.R. (2004), Characterization of Cd-Induced Molecular Events Prior to Cellular Damage in Primary Rat Hepatocytes in Culture: Activation of the Stress Activated Signal Protein JNK and Transcription Factor AP-1, Journal of Biochemical and Molecular Toxicology, 18, 133-142.

Kabata-Pendias A. and Pendias H. (2001), Trace Elements in Soils \& Plants, CRC Press, LLC (Third Ed) Boca Raton, Florida.

Kekec G., Sakcali M.S. and Uzonur I. (2010), Assesment of Genotoxic Effects of Boron on Wheat (Triticum aestivum L.) and Bean (Phaseolus vulgaris L.) by Using RAPD Analysis, Bulletin of Environmental Contamination and Toxicology, 84, 759-764.

Liu D., Jiang W. and Gao X. (2003), Effects of cadmium on root growth, cell division and nucleoli in root tip cells of garlic, Biologia Plantarum, 47(1), 79-83.

Liu W., Li P., Qi X., Zhou Q., Sun T. and Yang Y. (2005), DNA changes in barley (Hordeum vulgare) seedlings induced by cadmium pollution using RAPD analysis, Chemosphere, 61, 158-167.

Liu W., Yang Y.S., Li P.J., Zhou Q.X., Xie L.J. and Han Y.P. (2009), Risk Assessment of Cadmium Contaminated Soil on Plant DNA Damage Using RAPD and Physiological Indices, Journal of Hazardous Materials, 161, 878-883.

Lone M.I., He Z.L., Stoffella P.J. and Yang X.E. (2008), Phytoremediation of heavy metal polluted soils and water: progresses and perspectives, Journal of Zhejiang University Science, 9(3), 210-220.

Lorenc-Plucinska G. and Stobrawa K. (2005), Acclimation of poplar trees to heavy metals in polluted habitats: I. Carbohydrate metabolism in fine roots of Populus deltoids, Acta Societatis Botanicorum Poloniae, 74(1), 11-16.

Maurya R., Prasad S.M and Gopal R. (2008), LIF technique offers the potential for the detection of cadmium-induced alteration in photosynthetic activities of Zea Mays L., Journal of Photochemistry and Photobiology C: Photochemistry Reviews, 9, 29-35.

Meng H., Hua S., Shamsi I.H., Jilani G., Li Y. and Jiang L. (2009), Cadmium-induced stress on the seed germination and seedling growth of Brassica napus L. and its alleviation through exogenous plant growth regulators, Plant Growth Regulation, 58, 47-59.

Mishra S., Srivastava, S., Tripathi R.D., Dwivedi S. and Shukla M.K. (2008), Response of antioxidant enzymes in coontail (Ceratophyllum demersum L.) plants under cadmium stress, Environmental Toxicology, 23(3), $294-301$.

Mittler R. (2002), Oxidative Stress, Antioxidants and Stress Tolerance, Trends in Plant Science, 7, 405-410.

Mobin M. and Khan N.A. (2007), Photosynthetic activity, pigment composition and antioxidative response of two mustard (Brassica juncea) cultivars differing in photosynthetic capacity subjected to cadmium stress, Journal of Plant Physiology, 164(5), 601-610.

Nahar K., Khan M.G.U., Rahman M.S., Hasan C.M. and Rashid M.A. (2008), Secondary metabolites from Bryophyllum daigremontianum, Dhaka University Journal of Pharmaceutical Sciences, 7(2), 141-144.

Nedjimi B. and Daoud Y. (2009), Cadmium accumulation in Atriplex halimus subsp. schweinfurthii and its influence on growth, proline, root hydraulic conductivity and nutrient uptake, Flora-Morphol., Distrib., Functional Ecology Plants, 204(4), 316-324.

Ozturk F., Duman F., Leblebici Z. and Temizgul R. (2010), Arsenic accumulation and biological responses of watercress (Nasturtium officinale R. Br.) exposed to arsenite, Environmental and Experimental Botany, 69, 167-174.

Prasad M.N.V., Malec P., Waloszek A., Bojko M. and Strzalka K. (2001), Physiological responses of Lemna trisulca L. (duckweed) to cadmium and copper bioaccumulation, Plant Science, 161, 881-889.

Ross S.M. (1994), Sources and forms of potentially toxic metals in soil-plant systems. In: S.M. Ross, (Eds.) Toxic Metals in Soil-Plant Systems, Chicester: John Wiley pp. 3-25.

Salt D.E., Prince R.C., Pickering I.J. and Raskin I. (1995), Mechanisms of Cadmium Mobility and Accumulation in Indian Mustard, Plant Physiology, 109, 1427-1433.

Sandalio L.M., Dalurzo H.C., Gomez M., Romero-Puertas M.C. and del Rio L.A. (2001), Cadmium-induced changes in the growth and oxidative metabolism of pea plants, Journal of Experimental Botany, 52(364), 2115-2126.

Sanita di Toppi L. and Gabrielli R. (1999), Response to cadmium in higher plants, Environmental and Experimental Botany, 41, 105-130.

Seregin I.V. and Ivanov V.B. (2001), Physiological aspects of cadmium and lead toxic effects on higher plants, Russian Journal of Plant Physiology, 48, 523-544. 
Schutzendubel, A., Schwanz, P., Teichmann, T., Gross, K., Langenfeld-Heyser, R., Godbold, A. and Polle, A. (2001), Cadmium-induced changes in antioxidative systems, $\mathrm{H}_{2} \mathrm{O}_{2}$ content and differentiation in pine (Pinus sylvestris) roots. Plant Physiology, 127, 887-898.

Sun R.L., Zhou Q.X., Sun F.H. and Jin C.X. (2007), Antioxidative Defense and Praline/Phytochelatin Accumulation in A Newly Discovered Cd-Hyperaccumulator, Solanum nigrum L., Environmental and Experimental Botany, 60, 468-476.

Swaileh K.M., Hussein R. and Ezzughayyar A. (2008), Evaluating wastewater-induced plant genotoxicity using randomly amplified polymorphic DNA, Environmental Toxicology, 23, 117-122.

Uraguchi S., Mori S., Kuramata M., Kawasaki A., Arao T. and Ishikawa S. (2009), Root-to-shoot Cd translocation via the xylem is the major process determining shoot and grain cadmium accumulation in rice, Journal of Experimental Botany, 60(9), 2677-2688.

Wagner G.J. (1993), Accumulation of cadmium in crop plants and its consequences to human health, Advances in Agronomy, 51, 173-212.

Wan G., Najeeb U., Jilani G., Naeem M.S. and Zhou W. (2011), Calcium invigorates the cadmium-stressed Brassica napus L. plants by strengthening their photosynthetic system, Environmental Science and Pollution Research, 18(9), 1478-1486.

Wang Y., Qiao M., Liu Y. and Zhu Y. (2012), Health risk assessment of heavy metals in soils and vegetables from wastewater irrigated area, Beijing-Tianjin city cluster, China, Journal of Environmental Sciences, 24(4), 690-698.

Wu F.B. and Zhang G.-P. (2002), Alleviation of cadmium-toxicity by application of zinc and ascorbic acid in barley, Journal of Plant Nutrition, 25, 2745-2761.

Xu Q., Min H., Cai S., Fu Y., Sha S., Xie K., and Du K. (2012), Subcellular distribution and toxicity of cadmium in Potamogeton crispus L. Chemosphere, 89(1), 114-120.

Yang X.E., Long X.X., Ye Z.L., Calvert D.V. and Stoffella P.J. (2004), Cadmium tolerance and hyperaccumulation in a new Zn-hyperaccumulating plant species (Sedum alfredii Hance), Plant Soil, 259, 181-189.

Zhang G., Fukami M. and Sekimoto H. (2002), Influence of cadmium on mineral concentrations and yield components in wheat genotypes differing in Cd tolerance at seedling stage, Field Crops Research, 77, 93-98.

Zhang H.Y., Jiang Y.N., He Z.Y. and Ma M. (2005), Cadmium accumulation and oxidative burst in garlic (Allium sativum), Journal of Plant Physiology, 162, 977-984.

Zhao F.J., Ma Y., Zhu Y.G., Tang Z. and McGrath S.P. (2014), Soil contamination in China: current status and mitigation strategies, Environmental Science and Technology, 49(2), 750-759. 